Центр воєнно-стратегічних досліджень Національного університету оборони України імені Івана Черняховського, Київ

\title{
Підходи до імплементації стандартів НАТО у Збройних Силах України
}

Резюме: Розглянуті питання імплементації стандартів, прийнятих в арміях держав-членів НАТО, у Збройних Силах України для поліпшення ефективності оборонної реформи.

Ключові слова: Збройні Сили України; імплементація; оборонний менеджмент; оборонна реформа; стандарти НАТО.

Постановка проблеми. Оборонна реформа, що триває в Україні, має на меті набуття i підтримання силами оборони необхідного рівня бойової готовності та здатності до виконання завдань оборони держави, ефективного реагування на воєнні загрози за принципами і стандартами НАТО [1].

Імплементація військових стандартів армій держав-членів НАТО в Міністерстві оборони України (МО України), Збройних Силах України (ЗС України) та інших складових сил оборони (СО), наближення їx розвитку до принципів i стандартів, прийнятих в арміях розвинутих держав-членів НАТО є пріоритетним завданням.

Поняття імплементація

(англ. implementation, від латин. Impleo - здійснення, впровадження) полягає у фактичній реалізації міжнародного права в Україні, зокрема у Збройних Силах України, наближенні їх розвитку до принципів i стандартів, прийнятих в арміях розвинутих держав-членів HATO.

До форм імплементації європейських та євроатлантичних стандартів відносять реалізацію міжнародних зобов'язань, сформульованих у міжнародному праві, а саме: дотримання, виконання та використання.

Аналіз останніх досліджень i публікацій. Методологію наукового дослідження забезпечення імплементації обгрунтували у своїх працях С. Алексєєв, М. Блажиєвська, Є. Бурлай, Н. Кириловська, К. Кьотц, Л. Луць, М. Марченко, Ю. Ничка, К. Осакве, А. Піголкін, М. Раскалєй, О. Тихомиров, К. Трихліб, Л. Тіунова, Ю. Тихомиров, Дж. Хег, Х. Цвайгерт, В. Чіркін та інші [2]. Однак їх дослідження не торкаються оборонної сфери та військової справи.

Окремі питання розвитку сучасної воєнної справи, термінології та військової стандартизації у зазначених сферах у контексті імплементації та використання міжнародних стандартів НАТО у МО України, 3С України та інших складових СО розглянуті певним чином у наукових працях А. Семенченка, А. Павліковського, В. Фролова, Ф. Саганюка, В. Павленка та ін. [3-6].

У науковій літературі під час дослідження питань імплементації європейських та євроатлантичних стандартів у МО України, ЗС України та інших складових, ця тематика висвітлена недостатньо.

Метою статті $\epsilon$ пошук можливих підходів до імплементації європейських і євроатлантичних стандартів у МО України, 3С України та інших складових СО задля однакового їх тлумачення i застосування, наближення до принципів i стандартів, прийнятих в арміях розвинутих державчленів НАТО.

Викладення основного матеріалу. Україна прагне стати повноправним членом європейської та євроатлантичної спільноти, що потребує застосування загальноєвропейських і євроатлантичних підходів, насамперед, принципів і стандартів, прийнятих в арміях держав-членів НАТО

Cтандарт НАTO - це міжнародний договір, який регламентує загальні правила i порядок спільних дій, єдину термінологію й умови уніфікації технічних процесів, озброєння і військової техніки (ОВТ) та іншої матеріальної частини збройних сил державчленів НАТО і країн-партнерів.

Умовно їх виокремлюють у три групи:

адміністративні - визначають процеси управління та обміну інформацією, порядок роботи з документацією;

оперативні - спрямовані на оперативне планування застосування військ (сил);

матеріально-технічні - визначають єдині вимоги до ОВТ союзників, управління їх 
життєвим циклом, а також до кодифікації предметів забезпечення.

У збройних силах держав-членів НАТО ухвалені так звані стандартизаційні угоди (англ. Standardization Agreement - STANAG), які дають змогу спільно ефективно управляти силами і засобами збройних сил, проводити спільні операції та місії, бойову підготовку, технічне оснащення армій, розробляти та виробляти необхідне озброєння і військову техніку.

За наявними даними, усього нараховують близько двох тисяч стандартів НАТО, а угод про стандартизацію налічують майже 1200.

За даними МО України, станом на минулий рік Україна впровадила $16 \%$ стандартів НАТО. Головними проблемами у цій роботі називають брак системності в організації впровадження стандартів, нестача фахівців та недостатнє володіння ними англійською мовою, а також складність впровадження стандартів обмеженого доступу [7].
Запровадження стандартів

HATO передбачає проведення комплексу заходів, що включає прийняття рішення на застосування у MO України, 3С України та інших складових СО положень (норм, вимог) стандарту НАТО, розроблення на його основі відповідного акта законодавства чи нормативного документа (внесення відповідних змін та/чи доповнень до чинного документа), надання йому чинності в установленому порядку i його застосування у повсякденній діяльності у МО України, 3С України та інших складових CO. Тобто цінність та ефективність євроатлантичних стандартів забезпечується передусім їх імплементацією в національне законодавство України.

Удосконалення нормативно-правової діяльності МО України, ЗС України та інших складових СО відповідно до міжнародних стандартів грунтується на врахуванні досвіду та досягнень розвинених країн світу, насамперед держав-членів НАТО в оборонній та військовій сферах за усіма прийнятими ними базовими складовими розвитку спроможності військ (сил) (табл. 1).

Таблиця 1

\section{Базові складові спроможності армій держав-членів НАТО}

\begin{tabular}{|c|c|c|c|c|c|}
\hline $\begin{array}{c}\text { Складові спроможності } \\
\text { військ (сил) }\end{array}$ & США & Канада & $\begin{array}{c}\text { Велика } \\
\text { Британія }\end{array}$ & Австралія & Болгарія \\
\hline $\begin{array}{l}\text { Доктрина, концепція } \\
\text { Doctrine }\end{array}$ & $\bullet$ & $\bullet$ & $\bullet$ & & $\bullet$ \\
\hline Організація / Organization & $\bullet$ & $\bullet$ & $\bullet$ & $\bullet$ & \\
\hline $\begin{array}{l}\text { Колективна підготовка } \\
\text { Training }\end{array}$ & $\bullet$ & $\bullet$ & $\bullet$ & $\bullet$ & $\bullet$ \\
\hline Логістика / Materiel & & $\bullet$ & $\bullet$ & $\bullet$ & $\bullet$ \\
\hline Системи озброєння & $\bullet$ & $\bullet$ & $\bullet$ & $\bullet$ & \\
\hline $\begin{array}{l}\text { Командування і управління / } \\
\text { Leadership }\end{array}$ & $\bullet$ & $\bullet$ & & $\bullet$ & $\bullet$ \\
\hline Персонал / Personnel & $\bullet$ & $\bullet$ & $\bullet$ & $\bullet$ & $\bullet$ \\
\hline $\begin{array}{l}\text { Інфраструктура/ } \\
\text { Facilities }\end{array}$ & $\cdot$ & $\bullet$ & $\bullet$ & $\bullet$ & $\bullet$ \\
\hline Взаємосумісність/ Interoperability & $\bullet$ & & & & $\bullet$ \\
\hline Інформація & & $\bullet$ & $\bullet$ & & \\
\hline Дослідження & & $\bullet$ & & & \\
\hline
\end{tabular}

Розвиток спроможностей є домінуючим підходом стандартизації НАТО, що реалізується через нарощування (вдосконалення) необхідних їх базових складових. За цим підходом необхідного ефекту можна досягти за допомогою поліпшення конкретних базових компонентів (складових) спроможностей, які не потребують значних ресурсів, наприклад, через удосконалення (зміни) доктрин, організаційних структур, поліпшення системи відбору, навчання, підготовки та мотивації персоналу.

У разі неможливості розвитку спроможностей без значних затрат основні етапи їх розвитку включатимуть:

визначення (опис) спроможності (capability definition);

визначення стандартів, необхідних для розвитку спроможності та формування переліку вимог до сил і засобів (definition of standards and military requirements); 
закупівлю (постачання) необхідного озброєння, військової техніки та матеріальнотехнічного забезпечення (procurement);

розроблення настанов i здійснення підготовки персоналу (implementation through instruction and training);

бойове злагодження (навчання) перед застосуванням (redeployment preparations);

розгортання і застосування спроможності (deployment/ engagement of these capabilities);

оцінювання і висновки (аналіз та опрацювання пропозицій щодо коригування цільових пакетів (документів 3 розвитку) спроможностей (lessons learned) [4].

Для якіснішої діяльності за цими напрямами в Україні автори, виданої нещодавно у Національному університеті оборони України імені Івана Черняховського монографії [4] рекомендують виважено підходити i до переходу ЗС України на організаційні структури на кшталт J7, бо саме вони мають комплектуватися спеціально підготовленими за принципами і стандартами НАТО фахівцями, відповідати, передусім, за розроблення та вдосконалення доктринальних, тобто нормативно-правових і бойових документів, що визначають методологію планування, підготовку, забезпечення та військове управління застосуванням угруповань військ (сил) Збройних Сил України. Саме вони за принципами i стандартами НАТО мають розробляти та коригувати такі вітчизняні стандарти і нормативно-правові акти та керівні документи, а також замовлення на проведення наукових досліджень 3 цих питань для вдосконалення методології планування, підготовки і всебічного забезпечення операцій; аналізувати досвід військового управління під час застосування оперативно-стратегічних, оперативно-тактичних угруповань військ (сил) та готувати зміни до доктринальних документів тощо [4, с. $148-149]$.

Дослідження показують, що саме за таким підходом відповідно до пакету Цілей партнерства Україна-НАТО у МО України, 3С України та інших складових СО підлягають врахуванню 219 стандартів НАТО.

На початок 2020 року опрацьовано 98 (45\%), у тому числі запроваджено 80 (36 \%), на основі яких розроблено 94 національних та військових нормативно-правових актів i нормативних документів, 3 яких у 2019 році 25, а 121 в стадії опрацювання. Загалом у рамках Цілей партнерства в Україні розроблено 244 національних та військових нормативноправових актів і нормативних документів [7]. За функціональними ознаками ними охоплені усі сфери діяльності військ (сил) та їх розвитку: 138 таких нормативних документів 3 урахуванням стандартів НАТО розроблено i прийнято в оперативній сфері, 85 - 3 питань матеріального забезпечення ЗС України, 21 - в адміністративній сфері (табл. 2).

Таблиця 2

Військові документи, що розроблені в Україні з урахуванням стандартів НАТО

\begin{tabular}{|c|l|c|}
\hline \multicolumn{1}{|c|}{ Функціональні ознаки } & $\begin{array}{c}\text { Кількість } \\
\text { документів }\end{array}$ \\
\hline 1 & Цивільно-військове співробітництво & 3 \\
\hline 2 & Екологічна безпека та захист довкілля & 3 \\
\hline 3 & Воснна політика, безпека та стратегічне планування & 6 \\
\hline 4 & Військова поліція & 4 \\
\hline 5 & Застосування Військово-Морських Сил ЗС України & 19 \\
\hline 7 & Застосування Повітряних Сил ЗС України & 21 \\
\hline 8 & Застосування Сухопутних військ ЗС України & 4 \\
\hline 9 & Інформаційні та психологічні операції & 3 \\
\hline 10 & Оперативне управління (штабні процедури) & 5 \\
\hline 11 & Востосування Сил спеціальних операцій ЗС України & 7 \\
\hline 12 & Логістика & 1 \\
\hline 13 & Медичне забезпечення & 4 \\
\hline 14 & Морально-психологічне забезпечення & 15 \\
\hline 15 & РХБ захист & 1 \\
\hline 16 & Топогеодезичне і навігаційне забезпечення & 3 \\
\hline 17 & Гідрометеорологічне забезпечення & 17 \\
\hline 18 & Інженерне забезпечення & 2 \\
\hline 19 & Водолазне забезпечення & 1 \\
\hline 20 & Радіоелектронна боротьба & \\
\hline 21 & Військовий зв’язок та інформаційні системи & 5 \\
\hline Всього в оперативній сфері & 1 \\
\hline
\end{tabular}

Для впровадження стандартів НАТО у МО України створено єдиний орган військової стандартизації, функціями якого $є$ загальне керівництво та координація діяльності органів 
військового управління 3 впровадження стандартів НАТО, їх обліку та збереження. Під керівництвом кандидата військових наук, доцента А. Павліковського фахівцями Центру воєнно-стратегічних

досліджень

Національного університету оборони України імені Івана Черняховського розроблено військовий стандарт ВСТ 01.004.002 - 2019 (2) "Воєнна безпека. Стратегічне планування. Терміни та визначення”, який затверджений наказом начальника Управління стандартизації, кодифікації та каталогізації від 28.12.2019 № 28. Цей військовий стандарт призначений для застосування у МО України, 3С України та інших складових СО 3 урахуванням вимог сучасних законодавчих та інших нормативно-правових актів, а також принципів і стандартів, що прийняті в арміях держав-членів НАTO. Він може бути застосований і на підприємствах, в установах та організаціях усіх форм власності, що здійснюють на договірних засадах розроблення, виробництво i постачання продукції для ЗС України, виконують інші роботи та надають послуги.

Особливу увагу у Річній національній Програмі під егідою Комісії Україна-НАТО на 2020 рік, затвердженій Указом Президента України від 26.05.2020 року № 203, яка $\epsilon$ системним нормативним документом, що містить опис реформ за відповідними напрямами, визначає їх стратегічну мету, цілі, пріоритетні завдання і заходи, необхідні для забезпечення ефективної планомірної реалізації закріпленого Конституцією України стратегічного курсу держави на набуття повноправного членства в Організації Північноатлантичного договору приділено, зокрема, питанням активізації процесів досягнення відповідності критеріям членства в НАТО за допомогою прискорення внутрішньодержавних реформ, переведення сектору безпеки i оборони України на стандарти НАTO та поліпшення взаємосумісності $3 \mathrm{C}$ України 3 арміями держав-членів НАТО, зміцнення демократичного цивільного контролю над сектором безпеки i оборони, включаючи належне управління ним та реформування, гармонізацію чинного законодавства України iз законодавством держав-членів НАТО у сферах безпеки та оборони.
Висновок. Сучасний світ вступив у фазу активного інформаційного розвитку, що характеризується глобальністю інформаційних процесів. За цих умов війська (сили) покликані керуватися європейськими та євроатлантичними міжнародними принципами і стандартами.

Імплементація у МO та ЗС України, інших складових $\mathrm{CO}$ принципів і стандартів, прийнятих в арміях держав-членів НАТО, забезпечує планомірне нарощування боєздатності військ (сил) та їх спроможності, досягнення взаємосумісності із силами та засобами провідних країн світу, сприяе підвищенню ефективності використання державних ресурсів у сфері оборони та військового будівництва.

Подальші дослідження доцільно спрямувати на обгрунтування ефективніших підходів до використання у МО та ЗС України передового зарубіжного досвіду та принципів і стандартів армій держав-членів НАТО, що надалі сприятиме їх розвитку та функціонуванню.

\section{СПИСОК ВИКОРИСТАНОЇ ЛІТЕРАТУРИ}

1. План дій щодо впровадження оборонної реформи у 2016 - 2020 роках (дорожня карта оборонної реформи): затв. Міністерством оборони України 15.08.2016

2. Клименко О. Базові засади імплементації міжнародних нормативних документів у діяльності наукових бібліотек України: термінологічний аспект. URL: http://nbuviap.gov.ua/ (дата звернення: 12.01.2020).

3. Семенченко A. I. Ефективність державного управління у сфері забезпечення національної безпеки. URL: http: // defpol.org.ua/site/index.php/uk/ publikaci/doc_download/1 (дата звернення: 12.01.2020).

4. Оборонна реформа: системний підхід до оборонного менеджменту : монографія / $\begin{array}{lll}\text { А. Павліковський, } & \text { В. Фролов, Ф. Саганюк, }\end{array}$ В. Павленко та ін. ; за ред. А. Сиротенка. Київ : НУОУ, 2020. 306 с.

5. Військовий стандарт ВСТ $01.004 .002-2019$ (2) Воєнна безпека. Стратегічне планування. Терміни та визначення. [Чинний від 28-12-2019].

6. Воєнна безпека і оборона України : тлумачний словник нормативно-правових та наукових термінів й визначень / Саганюк Ф. В., Романов I. В., Воробйов В. М. та ін. Київ : ННДЦ і ВБ України, 2007. $186 \mathrm{c}$.

7. Зарембо К. Релізи: дослідження. URL: uacrisis.org (дата звернення: 10.07.2019). 


\section{Approaches to the implementation of NATO standards in the Armed Forces of Ukraine}

Annotation
The article discusses some issues of implementation of standards adopted in the armies of NATO memberstates in the Armed Forces of Ukraine to improve the effectiveness of defense reform.

Ways to implement European and Euro-Atlantic standards include the implementation of international obligations set out in international law, namely: compliance, implementation and use.

In the scientific literature of the study of the implementation of European and Euro-Atlantic standards in the Ministry of Defense of Ukraine, the Armed Forces of Ukraine and other components of the Defense Forces, this topic is currently insufficiently covered.

The aim of the article is to find effective approaches to the implementation of European and Euro-Atlantic standards in the Ministry of Defense of Ukraine, the Armed Forces of Ukraine and other components of the Defense Forces for uniform interpretation and application, approximation to the principles and standards adopted by NATO armies.

The armed forces of NATO member-states have adopted so-called standardization agreements (STANAG), which allow joint effective management of forces and means of the armed forces, conduct joint operations and missions, combat training, technical equipment of armies, develop the necessary armaments and military equipment.

According to available data, there are a total of about 2,000 NATO standards. And there are about 1,200 standardization agreements.

According to the Ministry of Defense of Ukraine, as of last year, Ukraine has implemented 16\% of NATO standards. The main problems in this work are the lack of system in the organization of implementation of standards, lack of specialists and insufficient knowledge of English, as well as the difficulty of implementing standards of limited access.

Implementation of NATO standards involves a set of measures, including the decision to apply in the Ministry of Defense of Ukraine, the Armed Forces of Ukraine and other components of the Defense Forces provisions (norms, requirements) of the NATO standard, development on its basis of legislation or regulations (amendments) and / or additions to the current document), giving it effect in the prescribed manner and its application in daily activities in the Ministry of Defense of Ukraine, the Armed Forces of Ukraine and other components of the Defense Forces. The value and effectiveness of Euro-Atlantic standards is ensured primarily by their implementation in the national legislation of Ukraine.

The analysis showed that the dominant approach to NATO standardization is the development of the capabilities of troops (forces), which is realized by building (improving) the necessary basic components of the DOTMLPFI system, which is actively used in the armies of NATO member-states.

Thus, studies show that the implementation in the Ministry of Defense of Ukraine, the Armed Forces of Ukraine and other components of the defense forces of the principles and standards adopted in the armies of NATO member states provides a systematic increase in the combat capability of troops (forces) leading countries of the world, contributes to improving the efficiency of state resources in the field of defense and military construction.

It is advisable to focus further work on substantiating more effective approaches to the use in the Ministry of Defense of Ukraine, the Armed Forces of Ukraine and other components of defense forces of foreign best practices and principles and standards of the armies NATO member-states, which will promote their development and functioning.

Keywords: Armed Forces of Ukraine; implementation; defense management; defense reform; NATO standards. 